\title{
Available phosphorus reduction in weaned piglets' diets containing phytase combined with butyric and benzoic acids
}

\author{
Redução do fósforo disponível na dieta de leitões desmamados \\ utilizando fitase associada aos ácidos butírico e benzoico
}

\author{
Luciana Moura Rufino ${ }^{1 *}$; Romão da Cunha Nunes²; José Henrique Stringhini²; \\ Alessandra Gimenez Mascarenhas'; ; Emmanuel Arnhold ${ }^{2}$; \\ Karyne Oliveira Coelho ${ }^{3}$; Fernanda Rodrigues Taveira Rocha ${ }^{4}$; Charles Kiefer ${ }^{5}$
}

\begin{abstract}
This study aimed to evaluate the reduction of available phosphorus $(\mathrm{Pa})$ in the diet of weaned piglets using phytase combined with butyric and benzoic acids. A total of 120 piglets with initial weight of 6.7 $\pm 0.02 \mathrm{~kg}$ were used in a randomized block design with six treatments: control; reduction of $0.15 \% \mathrm{~Pa}$ (Pa red); Phytase + Pa red; Phytase + butyric acid + Pa red; Phytase + benzoic acid + Pa red; Phytase + butyric acid + benzoic acid + Pa red; five replicates, with four animals each. The experimental diets had no influence on the fecal scores, Escherichia coli count, or the $\mathrm{pH}$ of the digestive tract. An improved villus:crypt ratio was found when the combination of phytase with butyric and benzoic acids was used. The histomorphometry of the jejunum and of the ileum showed no differences with respect to villus height, crypt depth, and villus:crypt ratio. The bones of the piglets fed with a diet containing reduced levels of available phosphorus showed less resistance to fracture. The levels of calcium in the raw bones were lower in the piglets that received a diet containing phytase and butyric acid. Reduced phosphorus deposition was observed in the bones of animals that received the diet containing phytase, butyric acid, and benzoic acid. It is concluded that the inclusion of phytase and butyric and benzoic acids, and their combination, in the diet of weaned piglets does not affect the $\mathrm{pH}$ of the stomach, duodenum, jejunum, ileum, cecum, and colon, and does not change the frequency of diarrhea or the E. Coli count. The association of butyric and benzoic acids with phytase in the diet of piglets after weaning improves the villus:crypt ratio of the duodenum. The use of phytase $(1000 \mathrm{UF} / \mathrm{kg})$ allows the formulation of diets for weaned piglets with a $0.15 \%$ reduction in the level of available phosphorus without damaging the concentration of calcium and phosphorus in the bones and without altering bone resistance.
\end{abstract}

Key words: Additives. Enzyme. Intestinal Health. Minerals. Organic Acids. Pigs.

\section{Resumo}

Realizou-se este estudo com o objetivo de avaliar a redução do nível de fósforo disponível (Pd) na dieta de leitões desmamados utilizando fitase associada aos ácidos butírico e benzóico. Foram utilizados 120 leitões, com peso inicial de $6,7 \pm 0,02 \mathrm{~kg}$, distribuídos em delineamento de blocos ao acaso com seis tratamentos: controle; redução de $0,15 \%$ de Pd (Pd red); Fitase + Pd red; Fitase + ácido butírico + Pd red;

${ }^{1} \mathrm{Dr}^{\mathrm{a}}$ em Ciência Animal, bolsista CAPES, Universidade Federal de Goiás, UFG, Goiânia, GO, Brasil. E-mail: rufinolu@hotmail. com; rufinolu@gmail.com

2 Profs., Programa de Pós-Graduação em Ciência Animal e do Programa de Pós-Graduação em Zootecnia, UFG, Goiânia, GO, Brasil. E-mail: romao@ufg.br; jhstring@uol.com.br; alegimenez09@hotmail.com; emmanuelarnhold@yahoo.com.br

3 Profa, Programa de Pós-Graduação em Desenvolvimento Rural Sustentável, UEG, São Luís de Montes Belos, GO. Bolsista PROBIP/UEG. Brasil. E-mail: kocoelho@yahoo.com.br

4 Prof ${ }^{a}$, UEG, São Luís de Montes Belos, GO, Brasil. E-mail: fernanda.rocha@ueg.br

5 Prof., Programa de Pós-Graduação em Ciência Animal, Universidade Federal de Mato Grosso do Sul, UFMS, Campo Grande, MS, Brasil. E-mail: charles.kiefer@ufms.br

* Author for corespondence 
Fitase + ácido benzóico + Pd red; Fitase + ácido butírico + ácido benzóico + Pd red; cinco repetições, com quatro animais cada. As dietas experimentais não influenciaram os escores fecais, a contagem de E. coli e o pH do trato digestivo. Verificou-se melhor relação vilo:cripta com a associação da fitase, com os ácidos butírico e benzóico. A histomorfometria do jejuno e do íleo não apresentaram diferenças para altura de vilosidades, profundidade de cripta e a relação vilo:cripta. Os ossos correspondentes aos leitões alimentados com a dieta com redução do nível de fósforo disponível apresentaram menor resistência à quebra. Os níveis de cálcio nos ossos crus foram menores para os leitões que receberam dieta com fitase e ácido butírico. Houve redução da deposição de fósforo nos ossos dos animais que receberam dieta com fitase, ácido butírico e ácido benzóico. Conclui-se que a inclusão de fitase e dos ácidos butírico, benzóico e sua associação na dieta de leitões desmamados não afeta o $\mathrm{pH}$ do estômago, duodeno, jejuno, íleo, ceco e cólon, não altera a frequência de diarreia e a contagem de E. coli. A associação dos ácidos butírico e benzóico com fitase na dieta dos leitões após a desmama melhora a relação vilo:cripta do duodeno. A utilização de fitase $(1.000 \mathrm{UF} / \mathrm{kg})$ possibilita a formulação de dietas para leitões desmamados com redução de $0,15 \%$ do nível de fósforo disponível sem prejudicar a concentração de cálcio e fósforo nos ossos e sem alterar a resistência óssea.

Palavras-chave: Ácidos Orgânicos. Aditivos. Enzima. Minerais. Saúde Intestinal. Suínos.

\section{Introduction}

Phytase has been investigated to reduce the use of inorganic sources of phosphorus in non-ruminants diets, since these species are less able to digest and take advantage of minerals, especially phosphorus, and amino acids complexed with phytate, in plant origin ingredients. Because organic acids are known to acidify the diet, if the $\mathrm{pH}$ of the digesta is reduced, the efficiency of phytase can be improved with the addition of these acids (ROCHA et al., 2008).

Acidifiers have been added to animal diets in order to minimize or avoid health problems such as diarrhea and edema disease, which compromise the performance of piglets after weaning, due to the stress experienced at this stage (TEIXEIRA et al., 2003). In general, the effect of acids in piglets depends on the amount of feed consumed, the quality of the diet, the age, and the health status of the nursery (CHIQUIERI et al., 2009).

Organic acids have an acidifying effect on feed by inhibiting or retarding the development of undesirable microorganisms. The inclusion of organic acids reduces the $\mathrm{pH}$ in the stomach, which shortens the time taken to reach an optimal $\mathrm{pH}$ value between 3 and 4, favoring the development of beneficial microorganisms (WALSH et al., 2007). Acidification of the diet decreases the rate of gastric passage and increases the time required for protein digestion (BRUMANO; GATTÁS, 2009).
Nonetheless, there are some limitations regarding the association of phytase with organic acids in piglet diets after weaning. Therefore, the aim of this study was to evaluate the influence of reduced phosphorus $(\mathrm{Pa})$ availability in the diet of weaned piglets, using phytase associated with butyric and benzoic acids, on the chemical, microbiological, and histo-anatomical aspects of the gastrointestinal tract and on the chemical and physical properties of bones.

\section{Materials and Methods}

The experimental trial was performed in the Swine Sector of the Department of Animal Production of the Veterinary and Animal Science School of the Federal University of Goiás and was approved by the Ethics Committee on Animal Use (CEUA-UFG), under protocol number 324/11.

A total of 120 barrow pigs, commercial hybrids, with an initial weight of $6.7 \pm 0.02 \mathrm{~kg}$ and a final weight of $25.0 \pm 2.78 \mathrm{~kg}$ were evaluated. The animals were distributed in a randomized block design with six experimental diets as follows: control diet (formulated to meet $100 \%$ of the animals' requirement with regard to available phosphorus); diet with available phosphorus reduced by $0.15 \%$ (Pa red); diet Pa red + phytase (formulated with phosphorus reduced by $0.15 \%$ 
associated with phytase); diet Pa red + phytase + butyric acid (formulated with phosphorus reduced by $0.15 \%$ associated with phytase and butyric acid); diet Pa red + phytase + benzoic acid (formulated with phosphorus reduced by $0.15 \%$ associated with phytase and benzoic acid); diet $\mathrm{Pa}$ red + phytase + butyric acid + benzoic acid (formulated with phosphorus reduced by $0.15 \%$ associated with phytase, butyric and benzoic acids), with five replicates with four animals each experimental unit.
Experimental diets (Tables 1 and 2) were isonutritive, with the exception of phosphorus and calcium levels, and were formulated according to the Brazilian Tables recommendations (ROSTAGNO et al., 2005). Micro granulated Ronozyme ${ }^{\circledR}$ Hiphos (M) phytase was used, which was obtained from the fungus Aspergillus oryzae at 1,000 UF/kg. During the experimental period, the animals were given free access to food and water.

Table 1. Percentage and nutritional composition of the experimental diets for the pre-initial phase $(7.0-15.0 \mathrm{~kg})$.

\begin{tabular}{|c|c|c|c|c|c|c|}
\hline \multirow[b]{2}{*}{ Feed } & \multicolumn{6}{|c|}{ Centesimal composition $\%$} \\
\hline & Control & Pa red* & $\begin{array}{l}\text { Pa red }+ \\
\text { PHYT }\end{array}$ & $\begin{array}{c}\text { Pa red }+ \\
\text { PHYT+BUA }\end{array}$ & $\begin{array}{c}\text { Pa red }+ \text { PHYT } \\
+ \text { BEA }\end{array}$ & $\begin{array}{c}\text { Pa red+PHYT } \\
+ \text { BUA+BEA }\end{array}$ \\
\hline Maize grain & 48.909 & 48.909 & 48.909 & 48.909 & 48.909 & 48.909 \\
\hline Soybean meal & 24.766 & 24.766 & 24.766 & 24.766 & 24.766 & 24.766 \\
\hline Soy oil & 4.000 & 4.000 & 4.000 & 4.000 & 4.000 & 4.000 \\
\hline Whole milk powder & 11.420 & 11.420 & 11.420 & 11.420 & 11.420 & 11.420 \\
\hline Dicalcium phosphate & 1.184 & 0.373 & 0.373 & 0.373 & 0.373 & 0.373 \\
\hline Limestone & 0.758 & 0.887 & 0.887 & 0.887 & 0.887 & 0.887 \\
\hline Iodized salt & 0.500 & 0.500 & 0.500 & 0.500 & 0.500 & 0.500 \\
\hline Sugar & 5.000 & 5.000 & 5.000 & 5.000 & 5.000 & 5.000 \\
\hline Kaolin & 1.100 & 1.782 & 1.780 & 1.480 & 1.030 & 0.730 \\
\hline L-Lysine $\mathrm{HCl}$ & 1.221 & 1.221 & 1.221 & 1.221 & 1.221 & 1.221 \\
\hline L-Threonine & 0.311 & 0.311 & 0.311 & 0.311 & 0.311 & 0.311 \\
\hline DL-Methionine & 0.203 & 0.203 & 0.203 & 0.203 & 0.203 & 0.203 \\
\hline L-Tryptophan & 0.178 & 0.178 & 0.178 & 0.178 & 0.178 & 0.178 \\
\hline Premix vitamin ${ }^{1}$ & 0.400 & 0.400 & 0.400 & 0.400 & 0.400 & 0.400 \\
\hline Premix mineral $^{2}$ & 0.050 & 0.050 & 0.050 & 0.050 & 0.050 & 0.050 \\
\hline Butyric acid & 0.000 & 0.000 & 0.000 & 0.300 & 0.000 & 0.300 \\
\hline Benzoic acid & 0.000 & 0.000 & 0.000 & 0.000 & 0.750 & 0.750 \\
\hline Phytase & 0.000 & 0.000 & 0.002 & 0.002 & 0.002 & 0.002 \\
\hline \multicolumn{7}{|c|}{ Calculated nutritional composition } \\
\hline ME (Mcal kg-1) & 3.375 & 3.375 & 3.375 & 3.375 & 3.375 & 3.375 \\
\hline PB (\%) & 21.00 & 21.00 & 21.00 & 21.00 & 21.00 & 21.00 \\
\hline Lysine dig. (\%) & 1.330 & 1.330 & 1.330 & 1.330 & 1.330 & 1.330 \\
\hline Met+Cist dig. (\%) & 0.719 & 0.719 & 0.719 & 0.719 & 0.719 & 0.719 \\
\hline Thre dig. (\%) & 0.927 & 0.927 & 0.927 & 0.927 & 0.927 & 0.927 \\
\hline Tryp dig. (\%) & 0.239 & 0.239 & 0.239 & 0.239 & 0.239 & 0.239 \\
\hline Phosphorus available (\%) & 0.380 & 0.230 & 0.230 & 0.230 & 0.230 & 0.230 \\
\hline Calcium (\%) & 0.789 & 0.640 & 0.640 & 0.640 & 0.640 & 0.640 \\
\hline
\end{tabular}

* Pa red $=$ Phosphorus available; Pa red + PHYT $=$ Phosphorus available Reduced with Phytase; Pa red + PHYT + BUA $=$ Phosphorus available Reduced with Phytase with Butyric Acid; Pa red + PHYT +BEA = Phosphorus available Reduced with Phytase with Benzoic Acid; Pa red+PHYT +BUA+BEA = Phosphorus available Reduced with Phytase with Butyric Acid with Benzoic Acid. ${ }^{1}$ Levels of guarantee $\mathrm{kg}^{-1}$ of product: folic acid $(87.50 \mathrm{mg})$; pantothenic acid (3000 mg); biotin (17.50 mg); choline (27.15 mg); colistin (10 g); niacin (7,500 mg); selenium (75 mg); vitamin A (15,000,000 IU); vitamin B1 (250 mg); vitamin B12 (3,750 mcg); vitamin B2 (1050 mg); vitamin B6 (500 mg); vitamin D3 (312,500 IU); vitamin E (6,250 IU); vitamin K3 (500 mg).

${ }^{2}$ Levels of guarantee $\mathrm{kg}^{-1}$ of product: copper $(15.97 \mathrm{~g})$; iron $(99.00 \mathrm{~g})$; iodine $(600.16 \mathrm{~g})$; manganese $(29.87 \mathrm{~g})$; zinc $(160.00 \mathrm{~g})$. PHYT: Phytase; BU: butyric; BE: benzoic. 
Table 2. Percentage and nutritional composition of the experimental diets for the initial phase (15.0-25.0 kg).

\begin{tabular}{|c|c|c|c|c|c|c|}
\hline \multirow[b]{2}{*}{ Feed } & \multicolumn{6}{|c|}{ Centesimal composition \% } \\
\hline & Control & Pa red* & $\begin{array}{l}\text { Pa red }+ \\
\text { PHYT }\end{array}$ & $\begin{array}{c}\text { Pa red }+ \\
\text { PHYT+BUA }\end{array}$ & $\begin{array}{c}\text { Pa red }+ \\
\text { PHYT }+ \text { BEA }\end{array}$ & $\begin{array}{c}\text { Pa red+PHYT } \\
+ \text { BUA+BEA }\end{array}$ \\
\hline Maize grain & 54.886 & 54.886 & 54.886 & 54.886 & 54.886 & 54.886 \\
\hline Soybean meal & 37.464 & 37.464 & 37.464 & 37.464 & 37.464 & 37.464 \\
\hline Soy oil & 2.000 & 2.000 & 2.000 & 2.000 & 2.000 & 2.000 \\
\hline Dicalcium phosphate & 1.432 & 0.621 & 0.621 & 0.621 & 0.621 & 0.621 \\
\hline Limestone & 0.720 & 0.849 & 0.849 & 0.849 & 0.849 & 0.849 \\
\hline Iodized salt & 0.500 & 0.500 & 0.500 & 0.500 & 0.500 & 0.500 \\
\hline Sugar & 1.000 & 1.000 & 1.000 & 1.000 & 1.000 & 1.000 \\
\hline Kaolin & 1.400 & 2.082 & 2.080 & 1.780 & 1.330 & 1.030 \\
\hline L-Lysine $\mathrm{HCl}$ & 0.080 & 0.080 & 0.080 & 0.080 & 0.080 & 0.080 \\
\hline DL-Methionine & 0.068 & 0.068 & 0.068 & 0.068 & 0.068 & 0.068 \\
\hline Premix vitamin ${ }^{1}$ & 0.400 & 0.400 & 0.400 & 0.400 & 0.400 & 0.400 \\
\hline Premix mineral $^{2}$ & 0.050 & 0.050 & 0.050 & 0.050 & 0.050 & 0.050 \\
\hline Butyric acid & 0.000 & 0.000 & 0.000 & 0.300 & 0.000 & 0.300 \\
\hline Benzoic acid & 0.000 & 0.000 & 0.000 & 0.000 & 0.750 & 0.750 \\
\hline Phytase & 0.000 & 0.000 & 0.002 & 0.002 & 0.002 & 0.002 \\
\hline \multicolumn{7}{|c|}{ Calculated nutritional composition } \\
\hline ME $(\text { Mcal kg-1 })^{*}$ & 3.230 & 3.230 & 3.230 & 3.230 & 3.230 & 3.230 \\
\hline $\mathrm{CP}(\%)$ & 19.240 & 19.240 & 19.240 & 19.240 & 19.240 & 19.240 \\
\hline Lysine dig. (\%) & 1.093 & 1.093 & 1.093 & 1.093 & 1.093 & 1.093 \\
\hline Met+Cyst dig (\%) & 0.661 & 0.661 & 0.661 & 0.661 & 0.661 & 0.661 \\
\hline Thre dig $(\%)$ & 0.723 & 0.723 & 0.723 & 0.723 & 0.723 & 0.723 \\
\hline Trypt dig (\%) & 0.241 & 0.241 & 0.241 & 0.241 & 0.241 & 0.241 \\
\hline Phosphorus available (\%) & 0.376 & 0.226 & 0.226 & 0.226 & 0.226 & 0.226 \\
\hline Calcium (\%) & 0.734 & 0.585 & 0.585 & 0.585 & 0.585 & 0.585 \\
\hline
\end{tabular}

* Pa red $=$ Phosphorus available; Pa red + PHYT $=$ Phosphorus available Reduced with Phytase; Pa red + PHYT + BUA $=$ Phosphorus available Reduced with Phytase with Butyric Acid; Pa red + PHYT + BEA = Phosphorus available Reduced with Phytase with Benzoic Acid; Pa red+PHYT +BUA+BEA = Phosphorus available Reduced with Phytase with Butyric Acid with Benzoic Acid. $\mathrm{ME}=$ Metabolizable Energy; $\mathrm{CP}=$ Crude Protein; Lysine dig. $=$ Lysine digestible; Met + Cyst $=$ Methionine + cysteine; Thre $=$ Threonine; Tryp = Tryptophan.

${ }^{1}$ Levels of guarantee $\mathrm{kg}^{-1}$ of product: folic acid (87.50 mg); pantothenic acid (3000 mg); biotin (17.50 mg); choline (27.15 mg); colistin (10 g); niacin (7,500 mg); selenium (75 mg); vitamin A (15,000,000 IU); vitamin B1 (250 mg); vitamin B12 (3,750 mcg); vitamin B2 (1050 mg); vitamin B6 (500 mg); vitamin D3 (312,500 IU); vitamin E (6,250 IU); vitamin K3 (500 mg).

${ }^{2}$ Levels of guarantee $\mathrm{kg}^{-1}$ of product: copper $(15.97 \mathrm{~g})$; iron $(99.00 \mathrm{~g})$; iodine $(600.16 \mathrm{~g})$; manganese $(29.87 \mathrm{~g})$; zinc $(160.00 \mathrm{~g})$. PHYT: Phytase; BU: butyric; BE: benzoic.

The fecal score was measured daily at $1600 \mathrm{~h}$ by a single evaluator, from piglets weighing $6.7 \pm 0.02$ to $25.0 \pm 2.779 \mathrm{~kg}$, which correspond to the prestarter and starter phases. The methodology used was adapted from that described by Sobestiansky and Barcellos (2007). The consistency of feces was classified according to the following criteria: 1 feces with normal consistency ( $>24 \%$ dry matter); 2 - pasty feces (22-24\% dry matter); 3 - creamy feces $(20-22 \%$ dry matter); $4-$ liquid feces $(<20 \%$ dry matter). Thus, when more than $20 \%$ of the animals presented diarrhea during the daily evaluation, the lot was considered affected. The intensity of diarrhea was classified according to the following criteria: if there were no records within 1 week, the experimental unit was considered not to have diarrhea; if there were records of diarrhea for 1-3 days, average diarrhea was considered present; and if there were records of diarrhea for 4 or more days, a high level diarrhea was considered present. 
When piglets reached $25.0 \pm 1.645 \mathrm{~kg}$ in weight, they were fasted for water and diet for 8 $\mathrm{h}$, followed by euthanasia, constituting one animal per replication, for a total of 30 piglets. Electrical desensitization was performed in the temporal fossa, animals were bled, and the abdomen was sequentially opened from the sternum to the pubis.

Samples of the intestinal content and urine were collected immediately following the euthanasia and evisceration of each slaughtered animal. These were placed in sterilized containers, identified, placed in isothermal boxes with dry ice, and sent for analysis as described by the American Public Health Association (APHA, 2001).

The $\mathrm{pH}$ of the contents of each of the three portions of the digestive system was measured with the aid of a portable $\mathrm{pH}$ meter immediately after the piglets were slaughtered. The $\mathrm{pH}$ of the experimental diets was also assessed in duplicate, in 20-g samples diluted in $30 \mathrm{~mL}$ distilled water and then homogenized using a magnetic stir bar and an electric stirrer, according to the method described by Giesting and Easter (1985).

With respect to the histomorphometry of the intestinal mucosa, fragments of approximately $2.0 \mathrm{~cm}$ in length were collected from the initial portions of the duodenum, jejunum, and ileum. The fragments were washed in distilled water, stretched by the serosa tunic, and fixed in $10 \%$ formaldehyde solution. After $24 \mathrm{~h}$, the samples were washed with distilled water and immersed in $70 \%$ alcohol solution. The samples were dehydrated in alcohol solution, diaphanized in xylol, embedded in paraffin, cut to $5 \mu \mathrm{m}$, fixed on slides, and stained with hematoxylin-eosin (HE) solution (PROPHET et al., 1992). Images were obtained with an optical microscope, with a $10 \times$ objective. Readings were taken using the Image-Pro Plus program 1.3.2 (1994). Straight lengths were selected and measured according to the adopted unit $(\mu \mathrm{m})$, with 30 villi and 30 crypts from each intestinal region, per animal, according to the recommendations made by Ramos et al. (2011).
In order to evaluate bone strength, the second and third metacarpal bones of the right hand were removed. The second bone was boiled for $10 \mathrm{~min}$ and the third was evaluated in natura. All bones were dissected and dried in a forced-ventilation oven for $72 \mathrm{~h}$ at $55^{\circ} \mathrm{C}$. The breaking strength was then determined in natura and in boiled bones using a universal test analyzer, Instron, series 3367, Grove City, United States, at a speed of $5 \mathrm{~mm} \mathrm{~min}^{-1}$. The rupture force was recorded in Newton $\left(\mathrm{N} \mathrm{mm}^{-1}\right)$.

The bones were degreased in a Goldfish Soxhlet Extractor and then crushed for the evaluation of $\mathrm{Ca}$ and $\mathrm{P}$. In order to determine the mineral matter, and to prepare the solution for $\mathrm{Ca}$ and $\mathrm{P}$ readings, $1 \mathrm{~g}$ of each sample was weighed and placed in the muffle until a temperature of $600^{\circ} \mathrm{C}$ was reached. Next, $5 \mathrm{~mL}$ of $\mathrm{HCl}$ (1:1) was added to the samples, which were then placed on a warming blanket to dehydrate the silica contained in the ashes and to decomplex the minerals to ease their solubilization and subsequent dosage. The samples were placed on filter paper, transferred to $100-\mathrm{mL}$ volumetric flasks, which were then filled with distilled water. Then, $50 \mathrm{~mL}$ of each sample was transferred to polyethylene packaging, identified, and sent to the laboratory. The $\mathrm{Ca}$ readings were obtained by atomic absorption spectrophotometry (ZAGATTO et al., 1979) and the P content was obtained by colorimetry (SARRUGE; HAAG, 1974).

The data regarding fecal score, stomach and small intestine $\mathrm{pH}$, histomorphometry of the small intestine, bone resistance, and concentration of $\mathrm{Ca}$ and $\mathrm{P}$ in the metacarpals were evaluated using the program R Development Core Team (2010) through non-parametric analysis, with the Kruskal-Wallis test at 5\% probability. With regard to the presence of Escherichia coli and Salmonella in the intestinal content and urine, the Kruskal-Wallis test at 5\% was used with the statistical program Statistical Analysis System version 9.2. The fecal score was evaluation using the methodology suggested by Sobestiansky and Barcellos (2007). 


\section{Results and Discussion}

Experimental diets had no influence $(p>0.05)$ on the fecal score percentages in the pre-initial and initial phases (Table 3). These results suggest that the occurrence of diarrhea was homogeneous among the treatments and that the inclusion of isolated or combined organic acids in the diets had no influence on its frequency. Diarrhea can be considered normal, even in piglets fed the control diet. Thus, the lack of effect of the acids in the diets may have occurred due to the highly sanitary conditions of the experimental assays.

Table 3. Percentage fecal scores of piglets in the pre-initial and initial stages fed with diets containing phytase and combinations of organic acids.

\begin{tabular}{|c|c|c|c|c|}
\hline \multirow{2}{*}{ Experimental diet } & \multicolumn{4}{|c|}{ Score $(\%)^{*}$} \\
\hline & 1 & 2 & 3 & 4 \\
\hline \multicolumn{5}{|l|}{ Pre-initial phase } \\
\hline Control & 61.5 & 15.2 & 21.3 & 2.0 \\
\hline Pa red & 58.4 & 13.4 & 21.7 & 6.4 \\
\hline Pa red+ PHYT & 66.0 & 18.8 & 13.2 & 2.0 \\
\hline Pa red + PHYT+ BUA & 59.9 & 16.2 & 19.1 & 4.8 \\
\hline Pa red + PHYT+ BEA & 71.9 & 14.3 & 10.1 & 3.6 \\
\hline Pa red + PHYT+ BUA+ BEA & 59.4 & 21.7 & 12.7 & 6.2 \\
\hline Value of $\mathrm{P}$ & 0.16 & 0.24 & 0.19 & 0.50 \\
\hline $\mathrm{CV}(\%)$ & 13.96 & 34.83 & 53.60 & 111.00 \\
\hline \multicolumn{5}{|l|}{ Initial phase } \\
\hline Control & 55.78 & 20.39 & 20.19 & 3.62 \\
\hline Pa red & 55.75 & 11.27 & 23.74 & 9.41 \\
\hline Pa red+ PHYT & 57.53 & 19.63 & 18.40 & 4.42 \\
\hline Pa red + PHYT + BUA & 65.25 & 22.67 & 8.93 & 3.13 \\
\hline Pa red + PHYT+ BEA & 62.32 & 21.58 & 12.75 & 3.33 \\
\hline $\mathrm{Pa}$ red $+\mathrm{PHYT}+\mathrm{BUA}+\mathrm{BEA}$ & 66.55 & 18.87 & 10.19 & 3.91 \\
\hline Value of $\mathrm{P}$ & 0.45 & 0.32 & 0.26 & 0.49 \\
\hline $\mathrm{CV}(\%)$ & 18.0 & 42.85 & 71.69 & 120.7 \\
\hline
\end{tabular}

* Absence of effect of the treatment ( $\mathrm{p}>0.05$ ) by the Kruskal-Wallis test. PHYT: Phytase; BUA: butyric acid; BEA: benzoic acid.

According to Rocha et al. (2008), there may be large variability among piglets in the post-weaning stages, with some animals exhibiting more resistance than others, which makes the fecal score results difficult to interpret. Freitas et al. (2006) reported a superior consistency of feces from piglets at 21-49 days of age when organic acids were used in the diet. Papatsiros et al. (2011) evaluated benzoic acid in the feed of weaned piglets and found a reduction in the severity of diarrhea.

No differences $(\mathrm{p}>0.05)$ were observed in the $E$. coli counts of the content of the small intestine of the piglets submitted to the distinct experimental diets (Table 4). The E. coli and Salmonella counts in the urine samples showed negative results. 
Table 4. Colony forming units (CFUs) of Escherichia coli, expressed as log values, in the duodenum, jejunum, and ileum of the piglets fed a diet with phytase and combinations of organic acids.

\begin{tabular}{lccc}
\hline Experimental diet & Duodenum* & Jejunum* & Ileum* \\
\hline Control & 0.00 & 1.23 & 1.49 \\
Pa red & 1.13 & 3.92 & 0.00 \\
Pa red+ PHYT & 1.31 & 2.20 & 3.00 \\
Pa red+ PHYT+ BUA & 0.00 & 1.39 & 2.29 \\
Pa red+ PHYT+ BEA & 0.00 & 1.93 & 1.48 \\
Pa red+ PHYT +BUA+ BEA & 0.00 & 5.42 & 0.93 \\
Value of P & 0.55 & 0.23 & 0.68 \\
CV $(\%)$ & 388.1 & 113.5 & 194.9 \\
\hline
\end{tabular}

* Absence of effect of the treatments ( $>0.05$ ) by the Kruskal-Wallis test. PHYT: Phytase; BUA: butyric acid; BEA: benzoic acid.

These results are consistent with those reported by Biagi et al. (2006), who observed no differences in the presence of this bacteria in the jejunum and ileum of piglets fed with gluconic acid and a control diet. Walsh et al. (2007) found lower proliferation of E. coli in piglets fed with acidified diets, relative to the control group without acidification. Freitas et al. (2006) also found a reduction in the level of E. coli in weaned piglets in the presence of organic acid supplementation. Walsh et al. (2012) observed that the prevalence of Salmonella in feces was reduced by the use of acids or probiotics in the water provided to weaned piglets. Wang et al. (2009), however, verified that the presence of Salmonella in feces was not affected, although a reduction in the number of E. coli colonies in weaned piglets who received a diet containing organic acid was observed. Piva and Grilli (2007) and Papatsiros et al. (2011) studied benzoic acid and observed bactericidal activity in the intestinal microbiota of swine.

In the present study, the $\mathrm{pH}$ values were not influenced $(p>0.05)$ by the experimental diets (Table 5). As shown, diets supplemented with butyric acid, benzoic acid, and their combination, do not affect the acidity of the digestive tract contents of the piglets. The results of this study are consistent with those of Gomes et al. (2011), who observed that supplementation of piglet diets with fumaric, lactic, and calcium propionate acids, or their combinations, did not influence the $\mathrm{pH}$ of the stomach and duodenum.

Table 5. Average $\mathrm{pH}$ of the experimental diets (ED), stomach contents (S), duodenum (D), jejunum (J), ileum (I), cecum $(\mathrm{Ce})$, and colon $(\mathrm{Co})$ of piglets fed a diet with phytase and combinations of organic acids.

\begin{tabular}{lccccccc}
\hline \multirow{2}{*}{ Experimental diet } & \multicolumn{7}{c}{ Variable* } \\
\cline { 2 - 8 } & ED & S & D & J & I & Ce & Co \\
\hline Control & 6.0 & 3.4 & 5.9 & 6.1 & 6.1 & 5.8 & 6.0 \\
Pa red & 5.8 & 2.8 & 5.4 & 6.4 & 6.4 & 6.0 & 6.2 \\
Pa red+ PHYT & 6.0 & 3.0 & 5.7 & 6.1 & 6.1 & 5.7 & 5.9 \\
Pa red+ PHYT+ BUA & 6.0 & 3.8 & 6.4 & 6.4 & 6.3 & 5.9 & 6.0 \\
Pa red+ PHYT+ BEA & 5.5 & 3.7 & 6.3 & 6.4 & 6.2 & 5.7 & 5.9 \\
Pa red+ PHYT+ BUA+ BEA & 5.5 & 3.8 & 6.1 & 6.5 & 6.1 & 6.0 & 6.1 \\
Value of P & - & 0.37 & 0.35 & 0.57 & 0.74 & 0.42 & 0.53 \\
CV $(\%)$ & - & 25.93 & 12.80 & 7.08 & 7.20 & 5.03 & 4.58 \\
\hline
\end{tabular}

* Absence of effect of the treatments $(\mathrm{p}>0.05)$ by the Kruskal-Wallis test. PHYT: Phytase; BUA: butyric acid; BEA: benzoic acid. 
Although there are reports in the literature on the improved action of organic acids for lowering the $\mathrm{pH}$ of the lower gastrointestinal tract (WANG et al., 2009), no effects of $\mathrm{pH}$ were found on the contents of the cecum and cervix of the piglets. Similarly, Walsh et al. (2007), studied weaned pigs fed with diets containing lactic acid and observed a lower fecal $\mathrm{pH}, 6$ days after weaning, relative to the $\mathrm{pH}$ at 33 days of age, when compared with animals of the same age who did not receive an acidified diet.
Regarding the histomorphometric evaluation of the small intestine, there was an effect $(p<0.05)$ on the villus height in the duodenum, with the highest height observed in piglets that received the control diet and the combination of butyric and benzoic acids with phytase (Table 6). Sakata et al. (1995) emphasized that short-chain fatty acids produced by the microbial fermentation of dietary fiber in the large intestine increased the proliferation of epithelial cells. Therefore, their inclusion in the diet may have contributed directly to the increased height of the villi.

Table 6. Villus height (VH), crypt depth (CD), and villus:crypt ratio (V:C) of the duodenum, jejunum, and ileum of piglets fed diets with phytase and combinations of organic acids.

\begin{tabular}{lccc}
\hline \multirow{2}{*}{ Experimental diet } & VH* & $\mathrm{CD}$ & $\mathrm{V}: \mathrm{C}^{*}$ \\
\cline { 2 - 4 } Control & $1.211 .50 \mathrm{a}$ & Duodenum & $2.59 \mathrm{~b}$ \\
Pa red & $704.55 \mathrm{~b}$ & 562.03 & $1.80 \mathrm{~b}$ \\
Pa red+ PHYT & $786.10 \mathrm{~b}$ & 445.67 & $4.00 \mathrm{~b}$ \\
Pa red+ PHYT+ BUA & $819.78 \mathrm{~b}$ & 516.68 & $3.53 \mathrm{~b}$ \\
Pa red+ PHYT+ BEA & $778.99 \mathrm{ab}$ & 604.11 & $2.20 \mathrm{~b}$ \\
Pa red+ PHYT+ BUA+ BEA & $1,049.60 \mathrm{ab}$ & 415.40 & $6.78^{\mathrm{a}}$ \\
Value of P & $<0.01$ & 0.35 & $<0.01$ \\
CV $(\%)$ & 17.41 & 25.02 & 35.45 \\
& & Jejunum & \\
Control & 719.93 & 593.32 & 1.20 \\
Pa red & 825.43 & 488.26 & 1.80 \\
Pa red+ PHYT & 851.13 & 453.27 & 2.00 \\
Pa red+ PHYT+ BUA & 804.95 & 495.82 & 1.40 \\
Pa red+ PHYT+ BEA & 744.31 & 498.92 & 1.40 \\
Pa red+ PHYT+ BUA+ BEA & 717.44 & 509.30 & 1.80 \\
Valor P & 0.19 & 0.75 & 0.34 \\
CV $(\%)$ & 7.84 & 3.52 & 2.54 \\
& & Ileum & \\
Control & 709.86 & 450.27 & 2.40 \\
Pa red & 686.14 & 467.98 & 1.40 \\
Pa red+ PHYT & 869.95 & 367.02 & 2.20 \\
Pa red+ PHYT+ BUA & 809.03 & 528.76 & 1.61 \\
Pa red+ PHYT+ BEA & 888.49 & 281.29 & 3.60 \\
Pa red+ PHYT+ BUA+BEA & 773.42 & 367.53 & 2.20 \\
Value of P & 0.47 & 0.14 & 0.30 \\
CV $(\%)$ & 4.20 & 2.93 & 1.54 \\
\hline
\end{tabular}

* Average values followed by distinct letters in the same column differ by Tukey's test $(\mathrm{p}<0.05)$. PHYT: Phytase; BUA: butyric acid; BEA: benzoic acid. 
An increased duodenal villus:crypt ratio $(\mathrm{V}: \mathrm{C})$ $(p<0.05)$ in animals receiving a combination of butyric and benzoic acids, and phytase in the diet was observed. Although there was no effect of the experimental diets on crypt depth, the piglets supplemented with butyric and benzoic acids, and phytase showed an improvement in the $\mathrm{V}: \mathrm{C}$ ratio. The use of organic acids in monogastric diets helps to maintain health and cell integrity, which contributes to a better $\mathrm{V}$ : $\mathrm{C}$ ratio. This result suggests that the association of benzoic and butyric acids with phytase has a positive effect on the intestinal mucosa of the piglets in the early stages of growth.

The results obtained are in agreement with those reported by Gheler et al. (2009), who observed an improvement in villi height and crypt depth in piglets fed with benzoic acid. However, the V:C ratio was not influenced by benzoic acid.

On the other hand, the villi height, crypt depth, and the $\mathrm{V}: \mathrm{C}$ ratio in the jejunum and ileum were not influenced $(\mathrm{p}>0.05)$ by the diets, demonstrating that organic acids do not affect these segments. Similarly, Gomes et al. (2011) observed that the addition of fumaric, lactic, and calcium propionate acids, or their combinations, had no influence on the small intestine morphometry of weaned piglets. Biagi et al. (2006) also found no effect of gluconic acid on the morphometry of the jejunum, ileum, and cecum of piglets after weaning.

Gomes et al. (2007) observed higher duodenal epithelium height relative to the jejunum and ileum in piglets fed with diets composed of fumaric, butyric, and formic acids, and their combination.

A lower $(p<0.05)$ resistance of raw bones from piglets fed with diets containing a $0.15 \%$ reduction in the level of available phosphorus was observed, relative to the other experimental diets (Table 7). This may be associated with the lower availability of phosphorus in the diet, which may have impaired the bone resistance of these piglets. It is also possible to infer that diets supplemented with phytase with a reduced level of available phosphorus were effective at increasing the available phosphorus in the food, and maintaining the resistance of the piglets' bones when compared to the control. A similar response was observed by Columbus et al. (2010), who verified that phytase improved bone resistance when compared to a diet that was deficient in phosphorus.

Table 7. Resistance of bone to breakage using raw and pre-boiled metacarpals of piglets fed diets with phytase and combinations of organic acids.

\begin{tabular}{lcc}
\hline \multirow{2}{*}{ Experimental diet } & Raw bone & Pre-boiled bone \\
\cline { 2 - 3 } Control & $\left(\mathrm{N} \mathrm{mm}^{-1}\right)^{1}$ & $(\mathrm{~N} \mathrm{~mm}+-1)$ \\
Pa red & $609.18 \mathrm{a}$ & 552.96 \\
Pa red+ PHYT & $485.56 \mathrm{~b}$ & 501.17 \\
Pa red+ PHYT+ BUA & $588.16 \mathrm{a}$ & 551.42 \\
Pa red+ PHYT+ BEA & $640.06 \mathrm{a}$ & 581.27 \\
Pa red+ PHYT+ BUA+ BEA & $619.08 \mathrm{a}$ & 605.84 \\
Value of P & $570.13 \mathrm{a}$ & 639.95 \\
CV $(\%)$ & 0.01 & 0.34 \\
\hline
\end{tabular}

${ }^{1}$ Average values followed by distinct letters in the same column differed by Tukey's test $(\mathrm{p}<0.05)$. PHYT: Phytase; BUA: butyric acid; BE: benzoic acid.

There was no effect $(p>0.05)$ of the diets on the resistance of pre-boiled bones. Thus, it may be inferred that the temperature $\left(100^{\circ} \mathrm{C}\right)$ at which the bones were exposed during sample preparation may have led to equivalent bone strengths, suggesting that this methodology may interfere with the final results. 
The calcium concentration in the raw metacarpal bones was not influenced $(\mathrm{p}>0.05)$ by the experimental diets (Table 8 ). With respect to the concentration of phosphorus, reduced levels $(p<0.05)$ were observed in the metacarpal bones of piglets who received a combined diet of phytase with butyric and benzoic acids relative to those that received diets with reduced phosphorous associated with phytase or butyric and benzoic acids. The association of the two acids in the piglet diet impaired the deposition of phosphorus in bone. On the other hand, no effect $(p>0.05)$ of the experimental diets was observed on calcium and phosphorus concentrations in the pre-boiled bones.

Table 8. Concentration of calcium $(\mathrm{Ca})$ and phosphorus $(\mathrm{P})$ in raw and pre-boiled metacarpal bones of piglets fed diets with phytase and combinations of organic acids.

\begin{tabular}{lcccc}
\hline \multirow{2}{*}{ Experimental diet } & \multicolumn{2}{c}{ Raw bone } & \multicolumn{2}{c}{ Pre-boiled bone } \\
\cline { 2 - 5 } & $\mathrm{Ca}(\%)^{1}$ & $\mathrm{P}(\%)^{1}$ & $\mathrm{Ca}(\%)$ & $\mathrm{P}(\%)$ \\
\hline Control & 16.13 & $7.17 \mathrm{ab}$ & 16.51 & 7.51 \\
Pa red & 17.97 & $8.10 \mathrm{ab}$ & 18.83 & 8.99 \\
Pa red+ PHYT & 16.07 & $8.37 \mathrm{a}$ & 15.90 & 7.50 \\
Pa red+ PHYT+ BUA & 16.46 & $8.36 \mathrm{a}$ & 15.82 & 8.16 \\
Pa red+ PHYT+ BEA & 15.11 & $8.48 \mathrm{a}$ & 15.18 & 8.27 \\
Pa red+ PHYT+ BUA+ BEA & 15.45 & $5.43 \mathrm{~b}$ & 14.00 & 6.87 \\
Value of P & 0.13 & 0.02 & 0.42 & 0.19 \\
CV $(\%)$ & 10.04 & 18.55 & 4.56 & 6.16 \\
\hline
\end{tabular}

${ }^{1}$ Average values followed by distinct letters in the same column differed by Tukey's test $(\mathrm{p}<0.05)$. PHYT: Phytase; BUA: butyric acid; BEA: benzoic acid.

According to Silva et al. (2005) the use of diets with reduced levels of phosphorus has no influence on the concentration of bone minerals when these are supplemented with phytase. However, it can be inferred that acidity caused by the dissociation of butyric acid resulted in a lower deposition of calcium and phosphorus in the bones, considering the result observed for the raw bones, even with the addition of phytase in the diets. Magnago et al. (2015) noted that the phytase concentration does not influence the levels of ash and phosphorus in the metacarpals of the animals. Saraiva et al. (2009) reported that animals genetically selected for muscle deposition favor weight gain at the expense of bone integrity when subjected to phosphorus deficiency.

\section{Conclusion}

The inclusion of phytase with butyric and benzoic acids, and their combination, in the diet of weaned piglets has no influence on the $\mathrm{pH}$ of the stomach, duodenum, jejunum, ileum, cecum, and colon. Furthermore, it does not change the frequency of diarrhea and the E. coli count, but does improve the villus:crypt ratio of the duodenum.

\section{Acknowledgements}

The authors acknowledge the Coordination for the Improvement of the Higher Education Personnel (CAPES) for the scholarship granted during the $\mathrm{PhD}$ thesis.

\section{References}

AMERICAN PUBLIC HEALTH ASSOCIATION APHA. Compendium of methods for the microbiological examination of foods. $4^{\text {th }}$ ed. Washington: APHA, 2001. $676 \mathrm{p}$.

BIAGI, G.; PIVA, A.; MOSCHINI, M.; VEZZALI, E; ROTH F. X. Effect of glycolic acid on piglet growth 
performance, intestinal microflora, and intestinal wall morphology. Journal of Animal Science, Champaign, v. 84, n. 2, p. 370-378, 2006.

BRUMANO, G.; GATTÁS, G. Alternativas ao uso de antibióticos como promotores de crescimento em rações de aves e suínos. Revista Eletrônica Nutritime, Viçosa, v. 6, n. 2, p. 856-875, 2009.

CHIQUIERI, J.; SOARES, R. T. R. N.; LYRA, M. S.; NERY, V. L. H.; FONSECA, J. B. Ácidos orgânicos na alimentação de leitões desmamados. Archivos de Zootecnia, Córdoba, v. 58, p. 610-616, 2009. Suplemento 1.

COLUMBUS, D.; NIVEN, S. J.; ZHU, C. L.; LANGE, C. F. M. de. Phosphorus utilization in starter pigs fed high-moisture corn-based liquid diets steeped with phytase. Journal of Animal Science, Champaign, v. 88, n. 12, p. 3964-3976, 2010.

FREITAS, L. S. de; LOPES, D. C.; FREITAS, A. F. de; COSTA CARNEIRO, J. da C.; CORASSA, A.; PENA, S. de M.; COSTA, L. F. Avaliação de ácidos orgânicos em dietas para leitões de 21 a 49 dias de idade. Revista Brasileira de Zootecnia, Viçosa, MG, v. 35, n. 4, p. 17111719, 2006.

GHELER, T. R.; ARAÚJO, L. F.; SILVA, C. C.; GOMES, G. A.; PRATA, M. F.; GOMIDE, C. A. Uso de ácido benzóico na dieta de leitões. Revista Brasileira de Zootecnia, Viçosa, MG, v. 38, n. 11, p. 2182-2187, 2009.

GIESTING, D. W.; EASTER, R. A. Response of starter pigs to supplementation of corn-soybean meal diets with organic acids. Journal of Animal Science, Champaign, v. 60, n. 5, p. 1288-1294, 1985.

GOMES, F. E.; FONTES, D. O.; SALIBA, E. O. S.; FERREIRA, W. M.; FIALHO, E. T.; SILVA, F. C. O.; SILVA, M. A.; CORRÊA, G. S. S.; SALUM, G. M. Ácido fumárico e sua combinação com os ácidos butírico ou fórmico em dietas de leitões recém-desmamados. Revista Brasileira de Zootecnia, Viçosa, MG, v. 59, n. 5, p. 1270-1277, 2007.

GOMES, F. E.; FONTES, D. O.; VASCONCELLOS, C. H. F.; SILVA, F. C. O. Ácido fumárico e sua combinação com os ácidos butírico ou fórmico em dietas de leitões recém-desmamados. Arquivo Brasileiro de Medicina Veterinária e Zootecnia, Belo Horizonte, v. 63, n. 3, p. 678-686, 2011.

IMAGE - PRO PLUS 1.3.2. The proven solution for image analysis: reference guide. Viçosa, MG: UFV, Departamento de Zootecnia, 1994. 504 p.

MAGNAGO, J. G. P.; HAESE, D.; KILL, J. L.; SOBREIRO, R. P.; DEL PUPPO, D.; SANT'ANNA, D.; SARAIVA, A.; LORENZONI. L. L.; PIMENTEL, R. B.
Níveis de fitase sobre o desempenho, parâmetros ósseos e bioquímicos de suínos alimentados com ração de origem vegetal sem inclusão de fosfato bicálcico. Ciência Rural, Santa Maria, v. 45, n. 7, p. 1286-1291, 2015.

PAPATSIROS, V. G.; TASSIS, P. D.; TZIKA, E. D.; PAPAIOANNOU, D. S.; PETRIDOU, E.; ALEXOPOULOS, C.; KYRIAKIS, S. C. Effect of benzoic acid and combination of benzoic acid with a probiotic containing Bacillus cereus var. toyoi in weaned pig nutrition. Polish Journal of Veterinary Sciences, Olsztyn, Kortowo, v. 14, n. 1, p. 117-125, 2011.

PIVA, A.; GRILLI, E. Role of benzoic, lactic and sorbic acid in vitro swine cecal fermentation. Veterinary Research Communications, Amsterdam, v. 31, n. 1, p. 401-404, 2007.

PROPHET, E. M.; MILLIS, B.; ARRINGTON, J. B.; SOBIN, L. H. Laboratory methods in histotechnology. Washington: America Registry of Pathology, 1992. 275 p.

R DEVELOPMENT CORE TEAM. R: a language and environment for statistical computing. Vienna: $\mathrm{R}$ Foundation for Statistical Computing, 2010.

RAMOS, L. S. N.; LOPES, J. B.; SILVA, S. M. M. S.; SILVA, F. E. S.; RIBEIRO, M. N. Desempenho e histomorfometria intestinal de frangos de corte de 1 a 21 dias de idade recebendo melhoradores de crescimento. Revista Brasileira de Zootecnia, Viçosa, MG, v. 40, n. 8, p. 1738-174, 2011.

ROCHA, E. V. H.; LIMA, J. A. F.; FIALHO, E. T.; ZANGERONIMO, M. G.; BERTECHINI, A. G.; RODRIGUES, P. B. Utilização de ácidos orgânicos e fitase em dietas para leitões na creche. Arquivo Brasileiro de Medicina Veterinária e Zootecnia, Belo Horizonte, v. 60, n. 3, p. 719-724, 2008.

ROSTAGNO, H. S.; ALBINO, L. F. T.; DONZELE, J. L.; GOMES, P. C.; FERREIRA, A. S.; OLIVEIRA, R. F.; LOPES, D. C. Tabelas brasileiras para aves e suínos: composição de alimentos e exigências nutricionais. 2. ed. Viçosa, MG: UFV, 2005. 186 p.

SAKATA, T.; ADACHI, M.; HASHIDA, M.; SATO, N.; KOJIMA, T. Effect of n-butyric acid on epithelial cell proliferation of pig colonic mucosa in short-term culture. Deutsche Tierarztliche Wochenschrift, Annover, v. 102, n. 4, p. 163-164, 1995.

SARAIVA, A.; DONZELE, J. L.; OLIVEIRA, R. F. M. de; ABREU, M. L. T. de; SILVA, F. C. de O.; HAESE, D. Níveis de fósforos disponíveis em rações para suínos de alto potencial genético para deposição de carne dos 30 aos 60kg. Revista Brasileira de Zootecnia, Viçosa, MG, v. 38, n. 7, p. 1279-1285, 2009. 
SARRUGE, J. R.; HAAG, H. P. Análises químicas em plantas. Piracicaba: ESALQ/USP, 1974. 56 p.

SILVA, H. O.; FIALHO, E. T.; LIMA, J. A. F.; SOUSA, R. V. de; SCHOULTEN, N.; SILVA, L. F. Efeito da fitase sobre a excreção e teor de minerais nos ossos de suínos na fase de crescimento. Agropecuária Técnica, João Pessoa, v. 26, n. 1, p. 54-59, 2005.

SOBESTIANSKY, J.; BARCELLOS, D. E. S. N. Doenças dos suínos. Goiânia: Cânone Editorial, 2007. $760 \mathrm{p}$.

TEIXEIRA, A. S.; CAVALCANTI, J. S.; OST, P. R.; SCHOULTEN, N. A. Probióticos em rações para frangos de corte utilizando farinha de carne e ossos com diferentes níveis de contaminação bacteriana. Ciência e Agrotecnologia, Lavras, v. 27, n. 4, p. 927-933, 2003.

WALSH, M. C.; ROSTAGNO, M. H.; GARDINER, G. E.; SUTTON, A. L.; RICHERT, B. T.; RADCLIFFE, J. S. Controlling Salmonella infection in weanling pigs through water delivery of direct-fed microbials or organic acids: Part II. Effects on intestinal histology and active nutrient transport. Journal of Animal Science, Champaign, v. 90, n. 8, p. 2599-2608, 2012.
WALSH, M. C.; SHOLLY, D. M.; HINSON, R. B.; TRAPP, S. A.; SUTTON, A. L.; RADCLIFFE, J. S.; SMITH, J. W.; RICHERT, B. T. Effects of acid LAC and kem-gest acid blends on growth performance and microbial shedding in weanling pigs. Journal of Animal Science, Champaign, v. 85, n. 2, p. 459-467, 2007.

WANG, J. P.; YOO, J. S.; LEE, J. H.; JANG, H. D.; KIM, H. J.; SHIN, L.; SEONG, S. I.; KIM, I. H. Effects of phenyllactic acid on growth performance, nutrient digestibility, microbial shedding, and blood profile in pigs. Journal of Animal Science, Champaign, v. 87, n. 10, p. 3235-3243, 2009.

ZAGATTO, E. A. G.; KRUG, F. J.; BERGAMIN FILHO, H.; JORGENSEN, S. S.; REIS, B. F. Determination of calcium, magnesium and potassium in plant material by flow injection atomic and flame emission spectrometry. Analytica Chimica Acta, Louisville, v. 104, n. 2, p. 279284, 1979. 